\title{
Ecological Responsibility of Students: Motivators and Demotivators of Their Environmental Behaviors
}

\author{
Lucyna Witek
}

\begin{abstract}
The purpose of the study was to answer the question to what extend young consumers behave environmentally responsible and what factors hinder and limit their environmental behaviors. The study included 342 students of the Rzeszów University of Technology. The direct survey method was applied. The study was conducted in January 2015. The results of the study showed that consumers had a positive attitude to environmental aspects, but a lot of inconsistencies in their statements could be noticed. On the one hand, they positively connote environmental issues and declare the possession of knowledge, and on the other hand, they use disposable plastic bags and save detergents weakly. A relatively small group of respondents declared buying organic products in their families. Laziness, lack of willingness to change existing habits and preference of values such as convenience, comfort, pleasure and aesthetics are the basic demotivators of ecological behavior of consumers. Consumers do not believe that their individual actions can improve the environment and they shift the responsibility to others.
\end{abstract}

Index Terms - ecological responsibility, green products, green consumers, socially responsible consumption students, survey, the Polish market.

\section{INTRODUCTION}

Environmental pollution and its negative consequences have become an important area of debate among scientists, businesses, non-profit organizations, political institutions and the media $[1,2]$. Finding a way to provide welfare for all people and ecological balance at the same time is one of the priority tasks of the mankind [3]. This gives the direction of development of the economy and identifies appropriate ways to conduct commercial organizations and other stakeholder groups [4]. Enterprises are increasingly looking for ways to reduce or eliminate possible negative environmental and social impacts [5]. They implement sustainable practices and strategic planning through environmental management and social action [6]. This situation brought about changes in the behavior of consumers who are increasingly sensitive to social issues, they are interested in ethical, moral and environmental aspects associated with the activities of commercial organizations [7-9].

In the scientific literature a growing interest in the perception of socially responsible consumer and socially res ponsible consumption can be seen [10,11]. One of the areas

Manuscript received February 20, 2017.

L. Witek is with Rzeszow University of Technology, The Faculty of Management, Department of Marketing, ul. Powstańców Warszawy 8, 35-959 Rzeszów, Poland (e-mail: lgarbacz@prz.edu.pl). of social responsibility of the consumer is its ecological responsibility associated with behavior and purchase of products that promote eco-friendly lifestyle, have no negative impact on the environment and contribute to the protection of the environment and a positive social change [12]. Consumers in developing countries are becoming more open to accepting ecological lifestyle [13]. Also in the Polish market there is an increase of environmental awareness and consumer interest in green products $[14,15]$.

The aim of the study was to answer the question to what extent young consumers behave environmentally responsible and what factors hinder and limit their environmental behaviors.

\section{LITERATURE REVIEW}

Numerous scientific studies indicate a growing interest in environmentally responsible consumption and green consumer [2, 7, 8, 9]. Environmental responsibility of the consumer is associated with avoidance of products having a negative impact on the environment and health. Ecological consumer behavior includes product purchases, the production, which uses the principle of minimizing the consumption of natural resources and materials, and the reduction of the amount of waste and pollution throu ghout the life cycle [5]. Green consumers feel anxiety which becomes the driving force for pro-environmental actions. They translate environmental issues on the consumption decisions in order to keep the environment in good condition for future generations. Even to the extent that in the case when the product has a lower quality and higher price compared to other available products he buys green product [16].

The main predictors of environmental behavior are knowledge, values, ecological attitudes and readiness for behavior [17]. Results of other studies show that collectivism, perceived consumer effectiveness, eco-literacy, and environmental concern are socio-psychological factors that have an impact on attitudes and purchasing decisions of environmentally friendly products [18]. Other authors draw attention to the ecological behavior because of altruism [16]. According reference [20] individual consumers' lifestyle has a greater impact on purchase of organic food than its demographic-social characteristics. Women are more involved in pro-environmental behavior, showing a higher degree of care for the environment than men [21]. A social group which is the most sensitive to environmental is sues has a lower age than the rest of society [16]. Due to the increasing awareness of the negative impact on the environment, consumers of younger generation are increasingly sensitive to green products when making a purchasing decision [22]. There are some studies where sex and age are not affected [19]. The 
motives of purchase of green products are concentrated in the area of health or the environment [23].

Polish consumers purchase organic products because of health not for environmental reasons [15, 24]. Similar conclusions are drawn in other developing countries [25]. For young consumers environmental issues are more important, while older consumers are considering green purchases in terms of health [26]. In the Polish market a demand for green products is still low. A demand growth is not as fast as in Western Europe. This is due to the limited availability of organic products, with the financial constraints of consumers, as well as their low level of knowledge and a lack of confidence in certified organic products [24].

\section{RESEARCH METHOD}

The study was conducted as part of a wider research project "Social and ecological aspects of consumer behavior." The survey entity were students of the Rzes zów University of Technology at the age of 19-25 years old. The study included 342 students, including $69 \%$ of women and $31 \%$ men. The study was conducted in January 2015. The direct survey method was applied. The study comprised this group a research shows that the attitude of young people in relation to the environment is positive. Young people have a greater criticis magainst environmental hazards than older consumers [27].

People at young age are more likely to accept new and innovative ideas than older people [28]. Many studies show that students have better pro-environmental behavior and attitudes than other social groups [29,30]. They are concerned not only about the present but the future impact of their behavior on the environment [22]. This is the group that will soon start a family, will generate income and they are involved in social and political life. They are open to the world, they have knowledge and skills necessary to use new technologies [31]. The pilot studies were carried out among 10 consumers. The survey referred to several key aspects of the attitudes and behavior of young consumers towards environmental issues, among others, knowledge, risk as sessment, sense of responsibility, willingness to give up the comfort and enjoyment, engagement in environmental action, i.e. recycling, using reusable bags, and buying green products. Particular attention was paid to the motives and behavior of environmentally friendly barriers and factors hindering such behavior. In the research the hypotheses $(\mathrm{H})$ were put. They took into account three spheres of attitudes, i.e. research, cognitive, affective and behavioral: $H(1)$ :The knowledge about the environment and its protection in the opinion of the respondents is high. H(2): Young consumers have a positive attitude to environmental issues. $\mathrm{H}(3)$ : Environmental behavior is low. H(4): The demotivator is a lack of faith in the efficacy of their actions and unwillingness to change habits.

\section{RESUlTS}

The consumers surveyed have a positive attitude to environmental aspects. As many as $85.9 \%$ of respondents said that protecting the environment was important. They are interested in information about the condition of environment and how to protect it. As many as $63.8 \%$ of respondents confirmed that this was a topic addressed in conversations with friends. The students believe that they have knowledge about threats to environment, how to protect the environment in everyday life and the consequences of negative actions of people and organizations (88.9\%). A large group of respondents $(61.8 \%)$ feel threatened because of environmental problems such as industrial pollution, waste, greenhouse effect, pollution, etc. The students surveyed are open to new ideas that promote eco-friendly lifestyle (Table I).

TABLE I:

CONSUMERS ATTITUDES TOWARDS ECOLOGICAL ISSUES (IN \%)

\begin{tabular}{lccc}
\hline $\begin{array}{l}\text { Consumers attitudes towards the } \\
\text { statement: }\end{array}$ & $\begin{array}{c}\mathrm{P} / \mathrm{Y} \\
*\end{array}$ & $\mathrm{~N} / \mathrm{N}^{* *}$ & $\begin{array}{c}\mathrm{IN} / \\
\mathrm{NPA} * *\end{array}$ \\
\hline $\begin{array}{l}\text { Environmental protection is } \\
\text { important }\end{array}$ & 85.9 & 2.1 & 12.0 \\
\hline $\begin{array}{l}\text { I believe that clean environment is } \\
\text { one of the highest value and should be } \\
\text { strictly protected }\end{array}$ & 33.9 & 24.3 & 41.8 \\
\hline $\begin{array}{l}\text { Among my friends ecological issues are } \\
\text { quite a popular subject }\end{array}$ & 63.8 & 8.0 & 18.2 \\
\hline $\begin{array}{l}\text { I am interested in information related } \\
\text { to environmental protection }\end{array}$ & 85.0 & 4.1 & 9.9 \\
\hline $\begin{array}{l}\text { I feel threatened because of } \\
\text { environmental problems such as } \\
\text { industrial pollution, waste, greenhouse } \\
\text { effect, pollution, etc }\end{array}$ & 61.8 & 12.0 & 25.2 \\
\hline
\end{tabular}

I'm able to give up the comfort,

pleasure for the improvement of the environment for example, snacking to

a place a few kilometers away, to

$29.0 \quad 45.8$

recycle the used equipment, medicines

or batteries

I have confidence in the ecological

declaration, slogans and certificates of $\quad 24.0 \quad 71.3 \quad 4.7$

manufacturers

\begin{tabular}{llll}
$\begin{array}{l}\text { I feel responsible for the poor } \\
\text { condition of environment }\end{array}$ & 45.0 & 38.9 & 16.1 \\
\hline
\end{tabular}

I am interested in new concepts that

promote eco-friendly lifestyles and

trends in the consumption which

recognize the principles of sustainable $\quad 57.9 \quad 26.9$

development, for example Slow Life,

buying second-hand products, Fair

Trade products

I have knowledge about environmental

threats, how to protect environment

$\begin{array}{llll}\text { in everyday life and the consequences } & 88.9 & 3.8 & 7.3\end{array}$

of negative actions of people and

organizations for environment

* Positive attitude/Yes; $* *$ Negative attitude/No; $* * *$ Indifferent attitude/ I do not pay attention.

Respondents declare economical use of natural resources and products which affect the environment negatively, but these measures are taken irregularly. There are many inconsistencies in the statements of the students. On the one hand, they connote positively environmental issues and declare the possession of knowledge, and on the other hand they use disposable plastic bags and save detergents poorly. A relatively small group declared shopping of green products in their families. They are distrustful of environmental slogans and declarations of manufacturers and retailers (24\%). The 
students do not want to give up comfort, convenience, pleasure, but also feel responsible for environment (Table II).

T ABLE II:

ECOLOGICAL BEHA VIOR OF CONSUMERS (IN \%)

\begin{tabular}{|c|c|c|c|c|}
\hline $\begin{array}{l}\text { Consumers } \\
\text { behavior }\end{array}$ & YRA* & $\mathrm{YN}^{* *}$ & $\mathrm{NE}^{* * *}$ & NO $* * * *$ \\
\hline $\begin{array}{l}\text { I save gas, } \\
\text { electricity and } \\
\text { water }\end{array}$ & 14.9 & 35.1 & 10.6 & 39.4 \\
\hline I segregate waste & 20.2 & 55.2 & 8.2 & 16.4 \\
\hline $\begin{array}{l}\text { I save detergents } \\
\text { and other } \\
\text { chemicals used in } \\
\text { the household }\end{array}$ & 6.4 & 26.9 & 9.0 & 57.7 \\
\hline $\begin{array}{l}\text { I am looking for } \\
\text { products in } \\
\text { returnable } \\
\text { packaging, } \\
\text { re-usable and } \\
\text { recyclable }\end{array}$ & 8.5 & 26.0 & 20.5 & 45.0 \\
\hline $\begin{array}{l}\text { While doing } \\
\text { shopping I use } \\
\text { disposable plastic } \\
\text { bags }\end{array}$ & 45.9 & 26.9 & 16.1 & 11.1 \\
\hline $\begin{array}{l}\text { In my family } \\
\text { home we buy } \\
\text { organic products }\end{array}$ & 4.1 & 28.1 & 14.1 & 53.7 \\
\hline
\end{tabular}

The basic demotivators of ecological behavior of consumers among students are laziness, lack of willingness to change existing habits and preference of values such as convenience, comfort, pleasure and aesthetics (Table III). Consumers do not believe that their individual actions can improve the environment and they shift the responsibility to others.

\section{CONCLUSIONS}

The studies have shown some discrepancies in consumer behavior. In spite of having knowledge of how to protect the environment, young consumers show little inclination to the real pro-environmental behavior. Reference [17] shows similar applications where high knowledge does not translate into positive attitudes towards recycling, resource conservation, buying green products, involvement in environmental actions and willingness to pay a higher price.

Knowledge of environmental is sues among young people in relation to the actual concern for the environment is disrupted and it results in the creation of environmental awareness in the growing Polish society. Environmental behavior of young Polish consumers are at a low level, although their attitude towards ecological value is positive and they declare a high level of knowledge. The high level of ecological knowledge of young consumers is not able to make changes in their emotional attitude to environmental issues and market behavior. Young consumers, in spite of distance and criticism in relation to the world around them and a positive attitude to ecology, are guided in their conduct on the market hedonism, seeking entertainment and pleasure and joy, which is also confirmed by [32]. Other studies argue with these results. Reference [33] shows that people aged 18-24 years old do not pay significant attention to environmental protection. Polish young consumers do not take environmental activities because they have a neutral attitude to environmental problems and low confidence in the effectiveness of their actions in the face of global problems [34].

TABLE III:

BARRIERS TO ECOLOGICAL BEHAVIOR (IN \%)

Why do you think other consumers do not take ecological action? (consumers can select up to 3 factors) Answer

\begin{tabular}{ll}
\hline $\begin{array}{l}\text { The condition of planet and the environment is } \\
\text { indifferent to them }\end{array}$ & 34.0 \\
\hline They are not particularly interested in the subject & 18.4 \\
\hline They do not see a need & 28.1 \\
\hline $\begin{array}{l}\text { They do not have awareness about the negative } \\
\text { consequences of the impact of their behavior on their } \\
\text { health, other people and animals }\end{array}$ & 47.1 \\
\hline $\begin{array}{l}\text { They prefer convenience, comfort, pleasure, aesthetics } \\
\text { than the ecological issues }\end{array}$ & 71.9 \\
\hline
\end{tabular}

They think that the government and enterprises should adopt pro-environmental action and that's enough

\begin{tabular}{|c|c|}
\hline They are too lazy & 88.9 \\
\hline $\begin{array}{l}\text { They do not believe that one person, the family can } \\
\text { improve the environment }\end{array}$ & 62.9 \\
\hline They have no knowledge about the environment & 14.6 \\
\hline They do not want to change existing habits & 81.0 \\
\hline Others & 6.7 \\
\hline
\end{tabular}

Positive processes in the Polish market are already noticeable, but it should be noted that the formation of ecologicalbehavior of Polish consumers goes a different way than in developed countries. It is connected with different social, economic, political and cultural factors.

For marketing managers it is a task. When directing a marketing message to young consumers it is important to reduce the distance to the environmental problems and encourage them to take action. To achieve this objective one can use modern tools such as ambient media, social media, marketing experience, buzz marketing, gaming, viral marketing, which will help to discuss ecological problems, share information and recommend green products [31]. An important question for managers is to build confidence in the young generation to take environmental actions and remove fears and emotional bonding with the company. The marketing communication strategy of green products managers must convince young consumers effectively about the 
environmental attributes of the product and remove barriers to their purchase. This study may contribute to the creation of green marketing strategy and help in market segmentation.

Inconsistencies in the statements of young consumers indicate a need for further studies that could explore the nature of the relationship between the cognitive, affective and behavioral elements of attitudes. This study gives a broader view of the ecological behavior of young consumers. Research shows new tasks for schools and universities, where young people derive much information about the environment, but at the same time they are not taught practical skills to apply that knowledge. In developing societies economic incentives may be an effective motivator of real environmental actions.

\section{REFERENCES}

[1] S.Bockman, N.Y. Razzouk and B. Sirotnik, "Going green - from left to center stage: An empirical perspective", Journal of the American Academy of Business, vol. 14, no. 2, pp. 8-17, 2009.

[2] M. Grimmer and M. Woolley, "Green marketing messages and consumers' purchase intentions: Promoting personal versus environmental benefits", Journal of Marketing Communications, vol. 20, issue 4, pp. 231-250, Aug2014. https://doi.org/10.1080/13527266.2012.684065

[3] L. Witek, "Influence of socio-demographic characteristics of consumers on attitudes towards Cause Related Marketing", Acta Universitatis Agriculturae et Silviculturae Mendelianae Brunensis, vol.64, issue 6, pp. 2173-2182, 2016. https://doi.org/10.11118/actaun201664062173

[4] H. Hall and L. Witek, "Conditions, Contemporary Importance and Prospects of Higher Education Marketing on the Example of Polish Universities", Ed. by: Iacob, AI, Conference: 3rd Global Conference on Business, Economics, Management and Tourism (BEMTUR) Location: Rome, IT ALY Date: NOV 26-28, 2015 , 3RD GLOBAL CONFERENCE ON BUSINESS, ECONOMICS, MANAGEMENT AND TOURISM, Procedia Economics and Finance, vol. 39, pp. 206-211, 2016. https://doi.org/10.1016/s2212-5671(16)30314-8

[5] L. Bednarova, L. Witek, R. Piętowska-Laska and A. Laska, "Assessment methods of the influence on environment in the context of eco-design process", edited by: M. Majernik, N. Daneshjo, M. Bosak, Slovakia: International Conference on Engineering Science and Production Management (ESPM), APR 16-17, 2015, Production Management and Engineering Sciences, pp. 15-20, 2016.

[6] L. Witek, "Consumer perception towards the Cause Related Marketing on the polish market", 2ND International Multidisciplinary Scientific Conference on Social Sciences \& Arts, SGEM 2015, Albena, Bulgaria Aug 26-Sep 01, 2015; SGEM 2015 : Political Sciences, Law, Finance, Economics And T ourism, Vol III, Economics And Tourism, Book Series: International Multidisciplinary Scientific Conferences on Social Sciences and Arts, pp. 139 - 145, 2015. https://doi.org/10.5593/sgemsocial2015/b23/s7.018

[7] A.A. Bailey, A. Mishra and M. F. Tiamiyu, "Green consumption values and Indian consumers' response to marketing communications", Journal of Consumer Marketing, vol. 33, issue 7, pp. 562-573, 2016. https://doi.org/10.1108/JCM-12-2015-1632

[8] K. Tsai-Feng and Yi-Chan T., "Effect of green consumption values on behavior: the influence of consumption attitude", International Journal of Arts \& Sciences, vol. 8, issue 8, pp. 119-130, 2015.

[9] A.K. Moser, "Thinking green, buying green? Drivers of pro-environmental purchasing behavior", Journal of Consumer Marketing, vol. 32, issue 3, pp.167-175, 2015. https://doi.org/10.1108/JCM-10-2014-1179
[10] K. Adomaviciute, "Relationship between utilitarian and hedonic consumer behavior and socially responsible consumption", Economics \& Management, vol.18, issue 4, pp. 754-760, 2013.

[11] S. Shobeiri, L. Rajaobelina, F. Durif and C. Boivin, "Experiential motivations of socially responsible consumption", International Journal of Market Research, vol. 58, issue 1, pp. 119-139, 2016. https://doi.org/10.2501/IJMR-2016-007

[12] S. M. Gordon-Wilson and P. Modi, „Personality and older consumers' green behaviour in the UK, "Futures", no 71, pp. 1-24, 2015. https://doi.org/10.1016/j.futures.2015.05.002

[13] Y. Li, Y. Lu, X. Zhang, L. Liu, M. Wang and X. Jiang, "Propensity of green consumption behaviors in representative cities in China", Journal of Cleaner Production, vol. 133, pp.1328-1336, Oct 2016 . https://doi.org/10.1016/j.jclepro.2016.06.012

[14] M. Strumioska-Kutra, Ekologiczna świadomość Polaków. Analiza wyników badań ilościowych z lat 1992-2011, Warszawa: Instytut na rzecz Ekorozwoju, 2012.

[15] B. Pilarczyk and R. Nestorowicz, Marketing ekologicznych produktów żywnościowych, Warszawa: Wolters Kluwer, 2010.

[16] C. D'Souza, M. Taghian, P. Lamb and R. Pretiatko, "Green decisions: demographics and consumer understanding of environmental labels", International Journal of Consumer Studies, vol.31, issue 4, pp.371-376, 2007. https://doi.org/10.1111/j.1470-6431.2006.00567.x

[17] A.M.F. do Paço, M.L.B Raposo and W.L. Filho, "Identifying the green consumer: A segmentation study", Journal of Targeting, Measurement and Analysis for Marketing, no 17, pp. 17-25, 2009 https://doi.org/10.1057/jt.2008.28

[18] Ch. Malik and N. Singhal, "Green Purchase Intention of Young Online Consumers: An Empirical Analysis”, Anvesha, vol. 9, issue 2, pp. 36-43, Apr-Jun2016.

[19] N.M. Suki, "Young consumer ecological behaviour: The effects of environmental knowledge, healthy food, and healthy way of life with the moderation of gender and age", Management of Environmental Quality: An International Journal, vol.24, issue 6, pp. 726-737, 2013. https://doi.org/10.1108/MEQ-02-2013-0010

[20] G.M. Chryssohoidis and A. Krystallis, Organic consumers' personal values research: testing and validating the list of values (LOV) scale and implementing a value-based segmentation task", Food Quality and Preference, no 16, pp. 585-599, 2005. https://doi.org/10.1016/j.foodqual.2005.01.003

[21] A. Franzen and R. Meyer, "Environmental attitudes in cross-national perspective: A multilevel analysis of the ISSP 1993 and 2000", European Sociological Review, vol. 26(2), pp.219-234, 2010 https://doi.org/10.1093/esr/jcp018

[22] M. Kanchanapibul, E. Lacka, X. Wang and H. K. Chan, "An empirical investigation of green purchase behaviour among the young generation", Journal of Cleaner Production, vol. 66, pp. 528-536, Mar2014. https://doi.org/10.1016/j.jclepro.2013.10.062

[23] P.Honkanen, S.O. Olsen and B. Verplanken, "Ethical value and motive driving organic food choice", Journal of Consumer Behaviour, vol. 5, no. 5, pp. 420-430, 2006. https://doi.org/10.1002/cb.190

[24] K. Gutkowska and I. Ozimek, Wybrane aspekty zachowań konsumentów na rynku żywności - kryteria zróżnicowania, Warszawa: Wydawnict wo SGWW, 2005.

[25] S. Raluca-Mihaela and A. Mihaela, "Determinants of romanian consumers' green purchase intention - a psychographic perspective", Annals of 'Constantin Brancusi' University of Targu-Jiu. Economy Series, issue 1, pp. 99-109, 2016.

[26] M.Wandel and A. Bugge, "Environmental concern in consumer evaluation of food quality", Food Quality and Preference, vol. 8, issue 1, pp.19-26, 1997. https://doi.org/10.1016/S0950-3293(96)00004-3 
[27] T. Burger, Świadomość ekologiczna spoleczeństwa polskiego u progu XXI wieku, Warszawa: Instytut na Rzecz Ekorozwoju, 2000.

[28] J.A. Ottman, E.R. Stafford and C.L. Hartman, "Avoiding green marketing myopia: ways to improve consumer appeal for environmentally preferable products, Environment, vol. 48, no.5, pp. 22-36, 2006. https://doi.org/10.3200/ENVT.48.5.22-36 https://doi.org/10.3200/ENVT.48.5.22-36

[29] D.S. Levine and J.M. Strube, "Environmental attitudes, knowledge, intentions and behaviors among college students", The Journal of Social Psychology, vol.152 (3), pp.308-326, 2012 https://doi.org/10.1080/00224545.2011.604363

[30] M. Cordano, S. Welcomer, R. F. Scherer, L. Pradenas and V. Parada, „A cross-cultural assessment of three theories of pro-environmental behavior: A comparison between business students of Chile and the United States", Environment and Behavior, vol. 43, pp. 634-657, 2011. https://doi.org/10.1177/0013916510378528

[31] L. Witek and H. Hall, "Prosumption use in creation of cause related marketing programs through crowdsourcing", Ed. by: Iacob, AI, Conference: 3rd Global Conference on Business, Economics, Management and Tourism (BEMTUR) Location: Rome, IT ALY Date: NOV 26-28, 2015, 3RD GLOBAL CONFERENCE ON
BUSINESS, ECONOMICS, MANAGEMENT AND TOURISM, Procedia Economics and Finance, vol. 39, pp. 212 - 218, 2016

[32] G. Adamczyk, „Wybrane aspekty zachowań młodych konsumentów w nowych realiach rynkowych", Handel Wewnętrzny, no 1(354), pp.5-16, 2014.

[33] CBOS, Badanie świadomości ekologicznej Polaków ze szczególnym uwzględnieniem energetyki przyjaznej środowisku, Warszawa: Instytut na Rzecz Ekorozwoju, 2011.

[34] A. Bołtromiuk, Świadomość ekologiczna Polaków zrównoważony rozwój, Warszawa: Instytut na Rzecz Ekorozwoju, 2009.

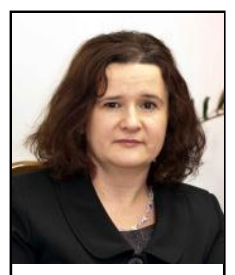

Lucyna Witek, PhD. is working with Rzeszow University of Technology, The Faculty of Management, Department of Marketing. She is an academic teacher at the university for 20 years. She has been a doctor of economic sciences since 2002 . Her scientific activity is focused on marketing, especially green marketing and green consumerism. 